OPEN ACCESS

Edited by:

Guangxu Liu,

Zhejiang University, China

Reviewed by:

Youji Wang,

Shanghai Ocean University, China

Wei Shi,

Zhejiang University, China

*Correspondence:

You Wang

wangyou@ouc.edu.cn

tThese authors have contributed equally to this work and share first authorship

Specialty section:

This article was submitted to

Aquatic Physiology,

a section of the journal

Frontiers in Physiology

Received: 19 August 2021 Accepted: 22 September 2021 Published: 14 October 2021

Citation:

Guo Y, Zhou B, Sun T, Zhang Y, Jiang $Y$ and Wang $Y$ (2021) An

Explanation Based on Energy-Related

Changes for Blue Mussel Mytilus edulis Coping With Seawater Acidification.

Front. Physiol. 12:761117. doi: 10.3389/fphys.2021.761117

\section{An Explanation Based on Energy-Related Changes for Blue Mussel Mytilus edulis Coping With Seawater Acidification}

\author{
Ying Guo ${ }^{1,2 t}$, Bin Zhou ${ }^{1,2 t}$, Tianli Sun ${ }^{3}$, Yaya Zhang ${ }^{1,2}$, Yongshun Jiang ${ }^{4}$ and You Wang ${ }^{1,2 *}$ \\ ${ }^{1}$ College of Marine Life Sciences, Ocean University of China, Qingdao, China, ${ }^{2}$ Laboratory for Marine Ecology and \\ Environmental Science, Pilot National Laboratory for Marine Science and Technology, Qingdao, China, ${ }^{3}$ National Marine \\ Hazard Mitigation Service, Beijing, China, ${ }^{4}$ Marine Science and Engineering College, Qingdao Agricultural University, \\ Qingdao, China
}

As ocean acidification $(\mathrm{OA})$ is gradually increasing, concerns regarding its ecological impacts on marine organisms are growing. Our previous studies have shown that seawater acidification exerted adverse effects on physiological processes of the blue mussel Mytilus edulis, and the aim of the present study was to obtain energy-related evidence to verify and explain our previous findings. Thus, the same acidification system $(\mathrm{pH}: 7.7$ or 7.1 ; acidification method: $\mathrm{HCl}$ addition or $\mathrm{CO}_{2}$ enrichment; experimental period: $21 \mathrm{~d}$ ) was set up, and the energy-related changes were assessed. The results showed that the energy charge (EC) and the gene expressions of cytochrome $C$ oxidase (COX) reflecting the ATP synthesis rate increased significantly after acidification treatments. What's more, the mussels exposed to acidification allocated more energy to gills and hemocytes. However, the total adenylate pool (TAP) and the final adenosine triphosphate (ATP) in M. edulis decreased significantly, especially in $\mathrm{CO}_{2}$ treatment group at $\mathrm{pH}$ 7.1. It was interesting to note that, TAP, ATP, and COXs gene expressions in $\mathrm{CO}_{2}$ treatment groups were all significantly lower than that in $\mathrm{HCl}$ treatment groups at the same $\mathrm{pH}$, verifying that $\mathrm{CO}_{2}$ induced acidification exhibited more deleterious impacts on $M$. edulis, and ions besides $\mathrm{H}^{+}$produced by $\mathrm{CO}_{2}$ dissolution were possible causes. In conclusion, energy-related changes in $M$. edulis responded actively to seawater acidification and varied with different acidification conditions, while the constraints they had at higher acidification levels suggest that $M$. edulis will have a limited tolerance to increasing $O A$ in the future.

Keywords: energy allocation, total adenylate pool, energy charge, adenosine triphosphate, cytochrome C oxidase, Mytilus edulis, seawater acidification

\section{INTRODUCTION}

Oceans have absorbed a large amount of anthropogenic carbon dioxide $\left(\mathrm{CO}_{2}\right)$ since the industrial revolution, leading to ocean acidification (OA; Caldeira and Wickett, 2003; Doney et al., 2009). The average seawater surface $\mathrm{pH}$ has declined by approximately 0.1 units compared with pre-industrial levels, and it is predicted to decline by an additional $0.3-0.4$ units by the end 
of this century (Fabry et al., 2008; Gattuso et al., 2015). OA has been reported to exerted adverse effects on marine organisms, including fertilization (Shi et al., 2017; Han et al., 2021), physiological responses (Peng et al., 2017; Zhao et al., 2017a,b, 2020), immune responses (Liu et al., 2016; Su et al., 2018), behavioral responses (Peng et al., 2017; Rong et al., 2018, 2020), and so on (Liu, 2021). Kroeker et al. (2011) findings indicated that OA decreased the diversity, biomass, and trophic complexity of benthic marine communities in reduced $\mathrm{pH}$ zones, with the highest reduction seen in the key calcifying species. In fact, natural $\mathrm{CO}_{2}$ vents in the Mediterranean Sea and Indo-Pacific are virtually devoid of calcifying organisms at pH 7.7 and below (Hall-Spencer et al., 2008). Owing to relatively low metabolic rates, poor acid-base regulation capacities and calcareous skeletal structures or shells, a large fraction of mollusk species presented a high vulnerability to OA (Thomsen et al., 2010; Wittmann and Pörtner, 2013; Wang and Wang, 2020). Bivalve mollusks, particularly in the early stages of their life, can react with decreased rates of growth and calcification, as well as a decreased shell strength toward elevated seawater $p \mathrm{CO}_{2}$ (Beniash et al., 2010; Gazeau et al., 2010; Talmage and Gobler, 2010; Gaylord et al., 2011; Stevens and Gobler, 2018). The slowness of growth and calcification seen in bivalve mollusks under acidic conditions was attributed to a higher energy consumption for the maintenance of physiological homeostasis (Lannig et al., 2010; Thomsen and Melzner, 2010; Melzner et al., 2020). For example, the total energy loss of Mytilus edulis in the treatments at $\mathrm{pH} 7.7$ and $\mathrm{pH} 7.4$ increased by 42 and 59\%, respectively, compared with that of the control at $\mathrm{pH}$ 8.0 (Thomsen and Melzner, 2010). Similarly, Beniash et al. (2010) found that Crassostrea virginica greatly increased its energy consumption and standard metabolic rate to maintain its internal stability when it was exposed to an acidic environment at $\mathrm{pH} 7.5$.

It is well documented that the organisms adopt different energy strategies when facing different acidic conditions. Organisms may compensate for the elevated energy demand during moderate acidification stress by increasing their energy intake, assimilation, and/or metabolic flux to cover the excessive demand for adenosine triphosphate (ATP). However, such compensation might be incomplete or impossible during extreme stress, and organisms would enter a metabolically depressed state to conserve energy and extend their survival time (Guppy and Withers, 1999). Melzner et al. (2011) found that strong $\mathrm{pCO}_{2}$ stress $(\mathrm{pH}<7.4)$ coupled with food limitation caused M. edulis to prefer allocating its resources toward the conservation of somatic mass, and the nacre was partially sacrificed because it required an extra energy input to maintain an intact nacre surface in the corrosive fluid. A recent study demonstrated that oysters Crassostrea gigas exhibited energy modulations with slight inhibition of aerobic metabolism, stimulation of anaerobic metabolism, and an increase in the glycolytic enzyme activity after exposure to seawater acidification (Cao et al., 2018). However, another earlier report declared that the long-term acclimation of $M$. edulis to elevated seawater $p \mathrm{CO}_{2}$ in the Western Baltic Sea resulted in an increase in aerobic metabolic rates rather than metabolic depression during moderate hypercapnia ( $\mathrm{pH}>7.4$; Thomsen and Melzner, 2010). It seemed that the energy responses of bivalves to seawater acidification were species-specific and varied under different acidic conditions.

Our previous studies showed that seawater acidification had adverse effects on M. edulis (Sun et al., 2016, 2017; Xu et al., 2020). The mortality rate of mussels increased significantly, while the rates of growth and calcification decreased considerably after acidification treatments. Ultrastructural impairments in gills, digestive glands, and hemocytes occurred, and the corresponding key physiological processes of ingestion, digestion, and immune functions were obviously influenced. What interested us most were the specific energy responses of $M$. edulis to acidified seawater and the consequent influences on M. edulis to cope with seawater acidification. Therefore, the present study focused on evaluating the energy responses of $M$. edulis to different acidification conditions. Understanding the energy strategies that $M$. edulis employs to address acidification stress and their biological limitations can serve as a quantitative basis for assessing the sublethal effects of seawater acidification on M. edulis and contribute to the prediction of the mussel population fate under future OA.

\section{MATERIALS AND METHODS}

\section{Organism Collection and Acclimation}

Adult individuals of $M$. edulis (shell length $48.88 \pm 0.72 \mathrm{~mm}$ and wet weight $7.20 \pm 0.58 \mathrm{~g}$ ) were collected in Laoshan Bay $\left(36^{\circ} 15 \mathrm{~N}, 120^{\circ} 40^{\prime} \mathrm{E}\right)$, Qingdao, China, and directly transferred to the experimental aquaria. The individuals were cleaned carefully and then acclimated in the experimental tanks (Vol. $=8 \mathrm{l}$; 30 mussels per tank) for a week before the experiments under the controlled conditions:temperature $15 \pm 1^{\circ} \mathrm{C}$; salinity $31 \pm 1$; pH $8.1 \pm 0.1$ (Sun et al., 2016, 2017). Natural seawater was filtered on a $0.45 \mu \mathrm{m}$ pore size membrane and completely renewed every day. Food algae, green microalgae Chlorella sp., was supplied daily to the holding tanks by natural gravity (approximately $1 \mathrm{ml} \mathrm{min}^{-1}$ ), and the final density in each tank was $1.5 \times 10^{5}$ cells ml ${ }^{-1}$.

\section{Experimental Design and Acidification System Setup}

The acidification system consisted of two acidification levels, one representing the near-future $\mathrm{OA}\left(\mathrm{pH} 7.7, \mathrm{pCO}_{2} \approx 1,500 \mathrm{ppm}\right.$; Orr et al., 2005) and the other mimicking the $\mathrm{CO}_{2}$ sequestration leak scenarios ( $\mathrm{pH} 7.1, p \mathrm{CO}_{2} \approx 5,000 \mathrm{ppm}$; Berge et al., 2006). Each acidification level was simulated by two different acidification methods of $\mathrm{HCl}$ addition (seawater was acidified by adding $1 \mathrm{M} \mathrm{HCl}$ ) and $\mathrm{CO}_{2}$ enrichment (seawater was bubbled with pure $\mathrm{CO}_{2}$ gas) according to our previous study (Sun et al., 2017). Seawater $\mathrm{pH}_{\mathrm{NBS}}$ was measured and adjusted by using a $\mathrm{pH}$ controller (pH/ORP-101, HOTEC, Taiwan), and the $\mathrm{pH}$ fluctuations were controlled within 0.08 units. The $\mathrm{pH}$ of the control was equal to the current average ocean surface value $\left(\mathrm{pH} 8.1, p \mathrm{CO}_{2} \approx 390 \mathrm{ppm}\right)$. The $\mathrm{pH}_{\mathrm{NBS}}$ and salinity were monitored daily, while the total alkalinity (AT) was measured 
weekly. All the other carbonate system variables were calculated using CO2SYS software according to Pierrot et al. (2006). The chemical parameters of the seawater acidified by $\mathrm{CO}_{2}$ were as follows (Table 1). The acclimated mussels were randomly divided into 5 groups, including 1 control group ( $\mathrm{pH}$ 8.1) and 4 acidifying treatment groups (2 $\mathrm{CO}_{2}$-treated groups: $\mathrm{pH} 7.7$ and $\mathrm{pH} 7.1 ; 2 \mathrm{HCl}$-treated groups: $\mathrm{pH} 7.7$ and $\mathrm{pH} 7.1$ ). Each group had three parallel groups with 15 individuals in. The experiments lasted for 21 days. During the experimental period, the temperature was kept at $15 \pm 1^{\circ} \mathrm{C}$ and the salinity of the experimental seawater was $31 \pm 1$. The green microalgae Chlorella sp. was provided once a day at a final density of $1.5 \times 10^{5} \mathrm{cells} \mathrm{ml}^{-1}$.

\section{Assessments of Energy Changes Sample Preparation}

Six mussels in each parallel group were randomly collected on the 21st day of the experiment. The gills and soft tissue (the whole tissues except shell) were sampled and then ground with phosphate-buffered saline (PBS, $0.14 \mathrm{M}$ sodium chloride, $3 \mathrm{~mm}$ potassium chloride, $8 \mathrm{~mm}$ disodium hydrogen phosphate dodecahydrate, and $1.5 \mathrm{~mm}$ potassium phosphate monobasic; $\mathrm{pH}$ 7.4), and the hemocytes were sampled according to Sun et al. (2017). The collected samples were sonicated on ice bath, and the homogenates were mixed with $20 \%(\mathrm{v} / \mathrm{v})$ perchloric acid at $1: 1(\mathrm{v} / \mathrm{v})$ and then centrifuged at $4000 \mathrm{~g}, 4^{\circ} \mathrm{C}$ for $10 \mathrm{~min}$. The supernatant was adjusted to $\mathrm{pH} 6.5$ with $1 \mathrm{M} \mathrm{KOH}$ and added to $10 \mathrm{ml}$ with $10 \%(\mathrm{v} / \mathrm{v})$ perchloric acid, of which the $\mathrm{pH}$ was preset to 6.5 with $1 \mathrm{M} \mathrm{KOH}$, and then filtered with a $0.22 \mu \mathrm{m}$ microporous membrane. A portion of the filtrate $(200 \mu \mathrm{l})$ was used for reversed-phase high-performance liquid chromatography analysis, and the remains were used for the quantitative analysis of the total proteins.

\section{Measurements of the Energy Changes in Gills, Soft Tissue and Hemocytes}

The total adenylate pool (TAP) is generally stable in mitochondria, and its content reflects not only the cell ability to produce high-energy phosphate compounds but also the cell energy reserve status (Xu et al., 2005). The energy charge (EC) was defined as the number of high-energy phosphate groups loaded in the total adenylate system, and it was proposed as a metabolic regulatory parameter reflecting the states of ATP regeneration and ATP utilization (Atkinson, 1968). TAP and EC could be calculated according to the following equations (Atkinson, 1968):

$$
\begin{aligned}
\mathrm{TAP} & =\mathrm{ATP}+\mathrm{ADP}+\mathrm{AMP} \\
\mathrm{EC} & =(\mathrm{ATP}+0.5 \mathrm{ADP}) /(\mathrm{ATP}+\mathrm{ADP}+\mathrm{AMP})
\end{aligned}
$$

The adenylate (ATP, ADP, and AMP) contents of the samples were measured according to the methods of Zhang et al. (2016) and Zhu et al. (2017) with some minor adjustments. We used ultrapure water instead of phosphate buffer as the solvent and $10 \%(\mathrm{v} / \mathrm{v})$ perchloric acid at $\mathrm{pH} 6.5$ for the preparation of the adenylate standards, adjusted the flow rate to $0.7 \mathrm{ml} \mathrm{min}-1$ and maintained the column temperature at $20^{\circ} \mathrm{C}$ during the analysis. The total proteins of the samples were determined by the Bradford (1976) method, and the ATP, ADP, and AMP contents were normalized to their corresponding total proteins.

\section{qRT-PCR Analysis of COXs Gene Expressions in Gills}

Cytochrome $\mathrm{C}$ oxidase $(\mathrm{COX})$ is the last and rate-limiting enzyme in the respiratory electron transport chain in cells and can cause the transmembrane proton electrochemical potential difference that ATP synthase then uses to synthesize ATP, so its activity directly affects the ATP synthesis rate (Keilin and Hartree, 1938). We used "Mytilus" and "Cytochrome C oxidase" as key words to search the gene bank and found 3 common gene sequences, COX I, COX II, and COX III, and 1 particular gene sequence, COX IV. Thus, 4 COX I-IV structural subunits of $M$. edulis were selected as target genes, and their expression profiles were determined by qRT-PCR analysis.

The extraction of total RNA and the synthesis of cDNA were performed according to Wang et al. (2011). The obtained cDNA mix was stored at $-80^{\circ} \mathrm{C}$ and diluted 8 -fold for subsequent qRT-PCR analysis.

qRT-PCR analysis was carried out according to Zhang et al. (2008) with the M. edulis actin gene as the endogenous control. The mRNA expressions of COXs were analyzed by the $2^{-\Delta \Delta \mathrm{Ct}}$ method (Livak and Schmittgen, 2001), and data were expressed in terms of the relative mRNA expressions. All the primers used for qRT-PCR were listed in Table 2.

\section{Statistical Analysis}

Data were expressed as means \pm standard deviation (SD) and analyzed by SPSS 26.0. The data were first tested for normal distribution and homogeneity of variance by Shapiro-Wilk's test and Levene's test, respectively. The significance of each difference between groups was assessed by one-way ANOVA

TABLE 1 | Key parameters (means $\pm \mathrm{SD}, n=3$ ) of carbonate chemistry in $\mathrm{CO}_{2}$ enriched seawater of different $\mathrm{pH}$ levels, including setting seawater $\mathrm{pH}$, measured $\mathrm{pH}$, total alkalinity $(\mathrm{TA})$, concentrations of bicarbonate $\left(\mathrm{HCO}_{3}{ }^{-}\right)$, carbonate ion $\left(\mathrm{CO}_{3}{ }^{2-}\right)$, carbonic acid $\left(\mathrm{H}_{2} \mathrm{CO}_{3}\right)$, and partial $\mathrm{CO}_{2}$ pressure $\left(p \mathrm{pO}_{2}\right)$, calculated saturation states of

\begin{tabular}{|c|c|c|c|c|c|c|c|c|}
\hline $\begin{array}{l}\mathrm{pH} \\
\text { (set) }\end{array}$ & $\begin{array}{c}\mathrm{pH} \\
\text { (measured) }\end{array}$ & $\begin{array}{c}\text { TA } \\
(\mu \mathrm{M})\end{array}$ & $\begin{array}{c}\mathrm{HCO}_{3}^{-} \\
(\mathrm{mM})\end{array}$ & $\begin{array}{l}\mathrm{CO}_{3}{ }^{2-} \\
(\mathrm{mM})\end{array}$ & $\begin{array}{c}\mathrm{H}_{2} \mathrm{CO}_{3} \\
(\mathrm{mM})\end{array}$ & 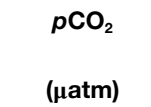 & $\Omega_{\mathrm{Ag}}$ & $\Omega_{\mathrm{Cal}}$ \\
\hline 8.1 & $8.10 \pm 0.05$ & $2098 \pm 89$ & $1733 \pm 79$ & $145 \pm 15$ & $14 \pm 1$ & $448 \pm 39$ & $2.25 \pm 0.25$ & $3.47 \pm 0.32$ \\
\hline 7.7 & $7.67 \pm 0.07$ & $2098 \pm 82$ & $1946 \pm 89$ & $60 \pm 8$ & $44 \pm 5$ & $1,353 \pm 107$ & $0.94 \pm 0.17$ & $1.45 \pm 0.26$ \\
\hline 7.1 & $7.06 \pm 0.06$ & $2098 \pm 77$ & $2059 \pm 74$ & $16 \pm 2$ & $188 \pm 19$ & $5,831 \pm 321$ & $0.24 \pm 0.03$ & $0.38 \pm 0.06$ \\
\hline
\end{tabular}
aragonite $\left(\Omega_{\mathrm{Ag}}\right)$, and calcite $\left(\Omega_{\mathrm{Ca}}\right)$. 
TABLE 2 | Sequences of the primers used in the experiment.

\begin{tabular}{|c|c|c|c|}
\hline Gene & Accession number & Direction & Primer sequence $\left(5^{\prime}-3^{\prime}\right)$ \\
\hline \multirow{2}{*}{ actin } & \multirow{2}{*}{ AF172606 } & $\mathrm{F}$ & СTCСACTCAATCCAAAAGCC \\
\hline & & $\mathrm{R}$ & AACCGTATGCGTGACACCA \\
\hline \multirow{2}{*}{$\operatorname{cox} 1$} & \multirow{2}{*}{ GU570522 } & $\mathrm{F}$ & CGTTCTTATTGTGGCTCTTCATT \\
\hline & & $R$ & CTCGCTCCCCПITATCTCC \\
\hline \multirow{2}{*}{ COX 11} & \multirow{2}{*}{ EU332534 } & $\mathrm{F}$ & AGAAAACCCCCAGGATACATT \\
\hline & & $\mathrm{R}$ & ACGAATGAAGTACATCCGACCT \\
\hline \multirow{2}{*}{ COX III } & \multirow{2}{*}{ U50219 } & $\mathrm{F}$ & GTAACTCAAGCCCATAAGAG \\
\hline & & $R$ & ATGCTCTTCTTGAATATAAGCGTACC \\
\hline \multirow{2}{*}{ COXN } & \multirow{2}{*}{ EU332541 } & $\mathrm{F}$ & АGATTATCCСTTCCCAGCACT \\
\hline & & $\mathrm{R}$ & GGCATTCATCTCAGAAAAGGTT \\
\hline
\end{tabular}

$F$, forward primer; $R$, reverse primer.

followed by a multiple comparison test (S-N-K). Any difference with a value of $p<0.05$ was considered significant.

\section{RESULTS}

\section{Energy Changes of $M$. edulis After Acidification Treatments}

In gills (Figure 1), TAP changed little in either $\mathrm{HCl}$ treatment group $(p>0.05)$ compared with the control group; TAP decreased significantly $(p<0.05)$ in both $\mathrm{CO}_{2}$ treatment groups compared with the control group, significantly lower at $\mathrm{pH} 7.1$ than $\mathrm{pH}$ 7.7. Similarly, ATP remained unchanged in both $\mathrm{HCl}$ treatment groups while declined significantly in the $\mathrm{CO}_{2}$ treatment group at $\mathrm{pH} 7.1(p<0.05)$. Significant increases of EC $(p<0.05)$ were observed in the $\mathrm{HCl}$ treatment group at $\mathrm{pH} 7.1$ and the two $\mathrm{CO}_{2}$ treatment groups, significantly higher at $\mathrm{pH} 7.1$ than $\mathrm{pH}$ 7.7.

The energy changes in soft tissue were similar to those in gills with some exceptions (Figure 2). For instance, both TAP and ATP in the $\mathrm{HCl}$ treatment group at $\mathrm{pH} 7.1$ decreased significantly in soft tissue $(p<0.05)$, while neither changed in gills.

TAP in hemocytes presented similar change trends to those seen in gills (Figure 3). ATP declined significantly in both $\mathrm{CO}_{2}$ treatment groups compared with the control group $(p<0.05)$, significantly lower at $\mathrm{pH} 7.1$ than $\mathrm{pH} 7.7$, while it only decreased significantly in the $\mathrm{HCl}$ treatment group at $\mathrm{pH} 7.1(p<0.05)$. EC showed no significant change in any treatment group compared with the control group, which partly accounted for the greater decrease in hemocytes ATP after acidification treatments.

In general, the energy changes in the $\mathrm{CO}_{2}$ treatment groups were more substantial than those in the $\mathrm{HCl}$ treatment groups at the same $\mathrm{pH}(p<0.05)$.

The ratios of the TAP in gills and hemocytes to that in soft tissue were calculated to evaluate the alterations of energy allocation after acidification treatments (Figure 4). At $\mathrm{pH}$ 7.7, the TAP ratios of gills and hemocytes changed little in either $\mathrm{CO}_{2}$ treatment groups or $\mathrm{HCl}$ treatment groups. At $\mathrm{pH}$ 7.1, the TAP ratios of gills changed little $(p>0.05)$, while the TAP ratios of hemocytes increased significantly $(p<0.05)$ in the $\mathrm{CO}_{2}$ treatment groups; the TAP ratios of both the gills and hemocytes increased significantly $(p<0.05)$ in the $\mathrm{HCl}$ treatment groups.

\section{Expression Profiles of COXs in Gills of M. edulis After Acidification Treatments}

The 4 COXs in gills analyzed in the present study all responded actively to seawater acidification, but the specific expression profiles varied with different COXs isoforms and acidification methods. The gene expression of COX I was significantly upregulated in each treatment group compared with the control $(p<0.05)$, with the highest upregulation $(1.7$-fold) observed in the $\mathrm{HCl}$ treatment at $\mathrm{pH} 7.1$, but there was no significant difference among the 4 treatment groups (Figure 5A). The gene expression of COX II increased more than 10-fold in each treatment group compared with the control $(p<0.05)$, with the highest upregulation (32.7-fold) observed in the $\mathrm{HCl}$ treatment group at $\mathrm{pH} 7.1$; the COX II gene levels were significantly higher at $\mathrm{pH} 7.1$ than $\mathrm{pH} 7.7$ under $\mathrm{HCl}$-induced acidification as well as $\mathrm{CO}_{2}$-induced acidification (Figure 5B); moreover, the COX II gene level was significantly higher in the $\mathrm{HCl}$ treatment group than the $\mathrm{CO}_{2}$ treatment group at the same $\mathrm{pH}(p<0.05)$. COX III presented quite different response patterns to $\mathrm{CO}_{2}$-induced seawater acidification compared with the other three COXs (Figure 5C). The gene expression of COX III changed little in either treatment group at $\mathrm{pH} 7.7$ $(p>0.05)$; at $\mathrm{pH} 7.1$ it increased significantly in the $\mathrm{HCl}$ treatment group $(1.97$-fold, $p<0.05)$ but decreased significantly $(0.39$-fold, $p<0.05)$ in the $\mathrm{CO}_{2}$ treatment group. The gene expression of COX IV remained unchanged at $\mathrm{pH} 7.7(p>0.05)$ while increased significantly in both treatment groups at $\mathrm{pH}$ $7.1(p<0.05)$, and the upregulation level $(7.5$-fold $)$ in the $\mathrm{HCl}$ treatment group was significantly higher than that (2.4-fold) in the $\mathrm{CO}_{2}$ treatment group $(p<0.05$; Figure 5D). Of the 4 COXs, COX II was most sensitive to the increase in the seawater acidity, and COX III presented the most different response patterns to the different acidification methods.

\section{DISCUSSION}

Organisms have been reported to adopt a variety of energy strategies to deal with stresses (Lannig et al., 2010; Thomsen and Melzner, 2010; Pan et al., 2015; Liu et al., 2020), and similar observations were obtained in the present study. Energyrelated changes were found in $M$. edulis exposed to acidified 


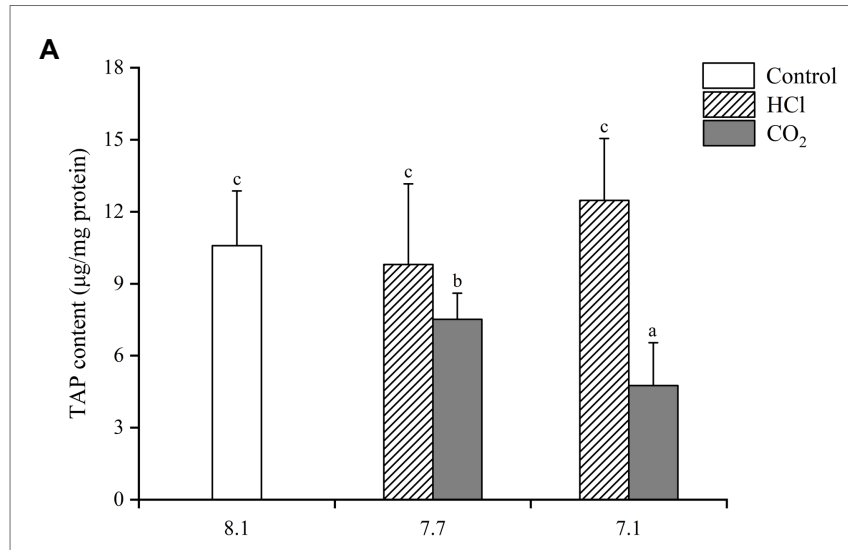

B

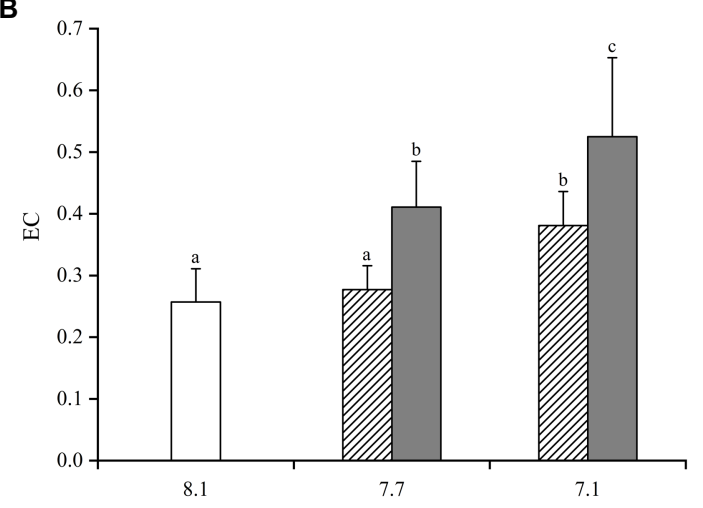

C

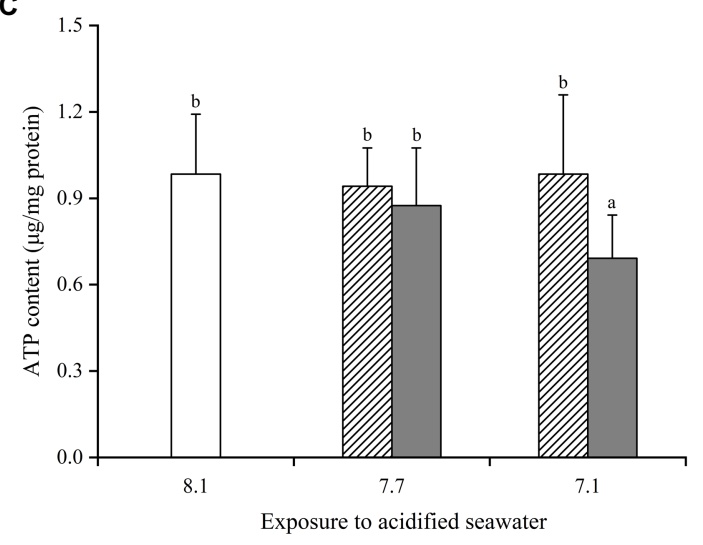

FIGURE 1 | Effects of seawater acidification induced by $\mathrm{HCl}$ addition and $\mathrm{CO}_{2}$ enrichment on TAP content (A), EC (B) and ATP content (C) in gills of Mytilus edulis. Data were expressed as means $\pm \mathrm{SD}(n=6)$. Different letters represent significant differences among experimental groups $(p<0.05)$.

seawater, including energy reserve (TAP), energy flux (ATP), ATP synthesis rate (EC), energy allocation (TAP ratios), and COXs gene expressions. However, the specific energy changes varied with different $\mathrm{pH}$ levels and acidification methods.

The TAP content directly reflects the energy storage status and the ability to generate ATP (Xu et al., 2005). Generally, the TAP content is stable under normal conditions, although the ratios of ATP, ADP, and AMP fluctuate to some extent with different oxidative phosphorylation levels. In the present study, we observed that the TAP contents all decreased

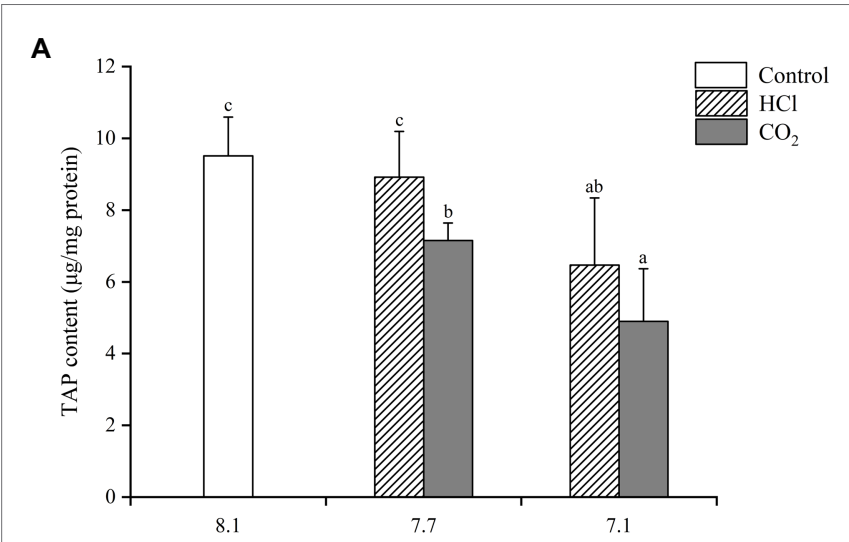

B

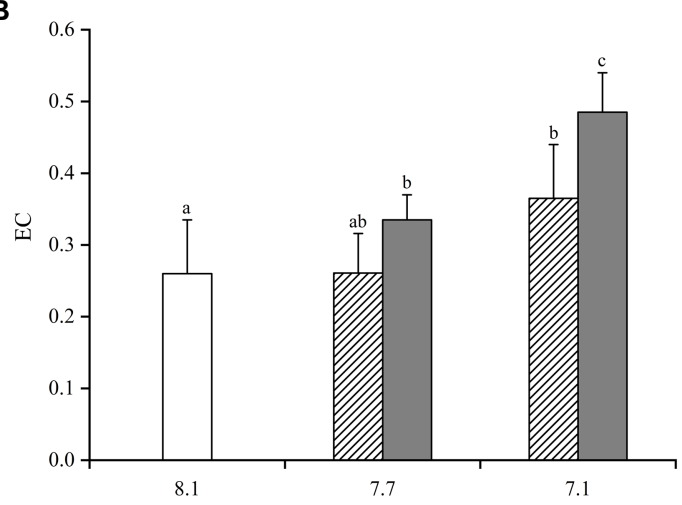

C

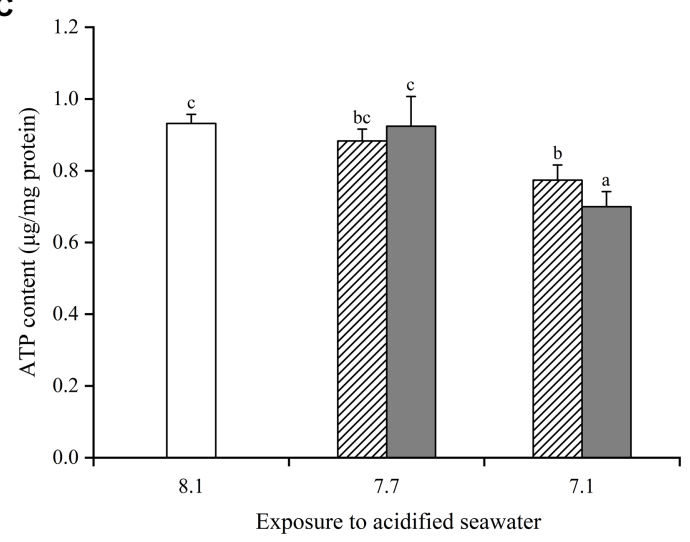

FIGURE 2 | Effects of seawater acidification induced by $\mathrm{HCl}$ addition and $\mathrm{CO}_{2}$ enrichment on TAP content (A), EC (B) and ATP content (C) in soft tissue of $M$. edulis. Data were expressed as means $\pm \mathrm{SD}(n=6)$. Different letters represent significant differences among experimental groups $(p<0.05)$.

significantly $(p<0.05)$ in the three sampled tissues of $M$. edulis exposed to $\mathrm{CO}_{2}$-acidified seawater (both $\mathrm{pH} 7.7$ and 7.1 treatments), so was the TAP content in soft tissue of M. edulis exposed to $\mathrm{HCl}$-acidified seawater at $\mathrm{pH} 7.1$, which meant that the potential stocks for ATP synthesis decreased. Our previous study reported that seawater acidification damaged the ultrastructure of the gills and digestive glands and prohibited digestive enzyme activities, which ultimately resulted in a decline in feeding and digestion abilities (Xu et al., 2020). We believed that there might be a correlation between the decrease in TAP and the weakening of the assimilation ability. 


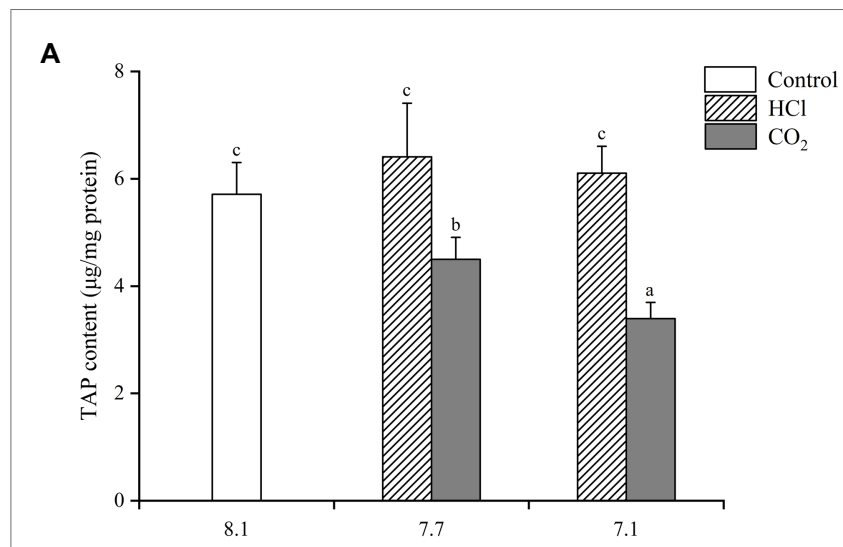

B

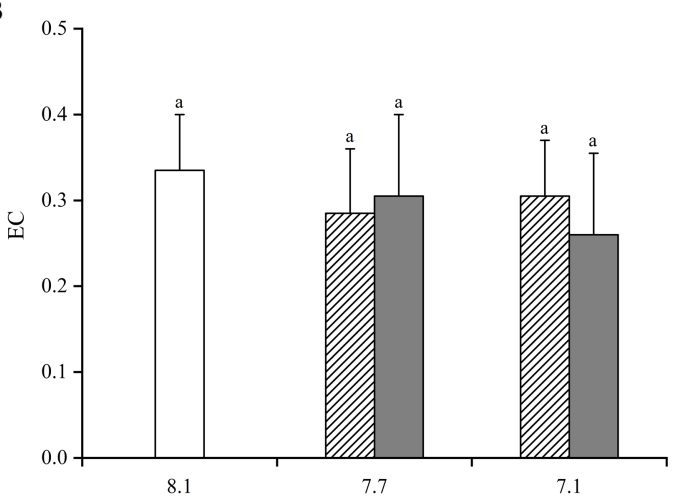

C

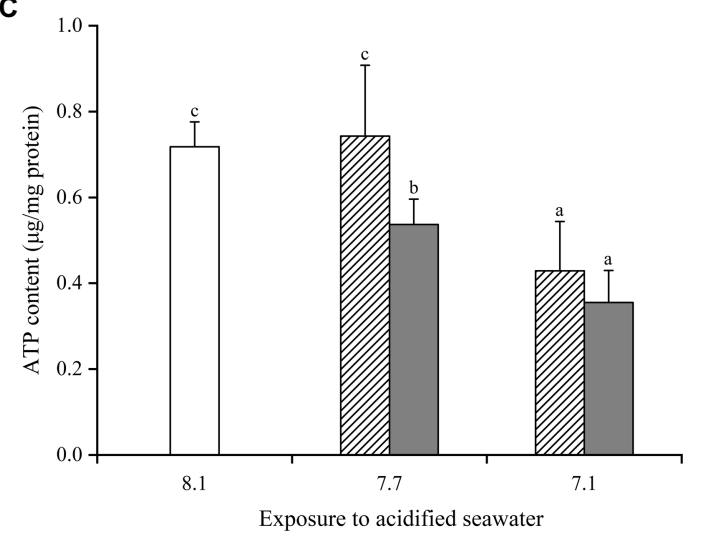

FIGURE 3 | Effects of seawater acidification induced by $\mathrm{HCl}$ addition and $\mathrm{CO}_{2}$ enrichment on TAP content (A), EC (B) and ATP content (C) in hemocytes of $M$. edulis. Data were expressed as means $\pm S D(n=6)$. Different letters represent significant differences among experimental groups $(p<0.05)$.

EC is an effective index indicating the ATP synthesis rate. We observed an elevation of EC in soft tissue but a decrease in ATP content in both $\mathrm{HCl}$ and $\mathrm{CO}_{2}$ treatment groups at $\mathrm{pH} 7.1$, and similar situation was found in gills in $\mathrm{CO}_{2}$ treatment group at $\mathrm{pH}$ 7.1. There seemed to be a paradox between the ATP synthesis rate and ATP availability. A reasonable explanation might be that the excessive energy consumption induced by the enhanced acidification was beyond the energy compensation ability and that the equilibrium point between ATP production and consumption could not be reached. Moreover, higher EC

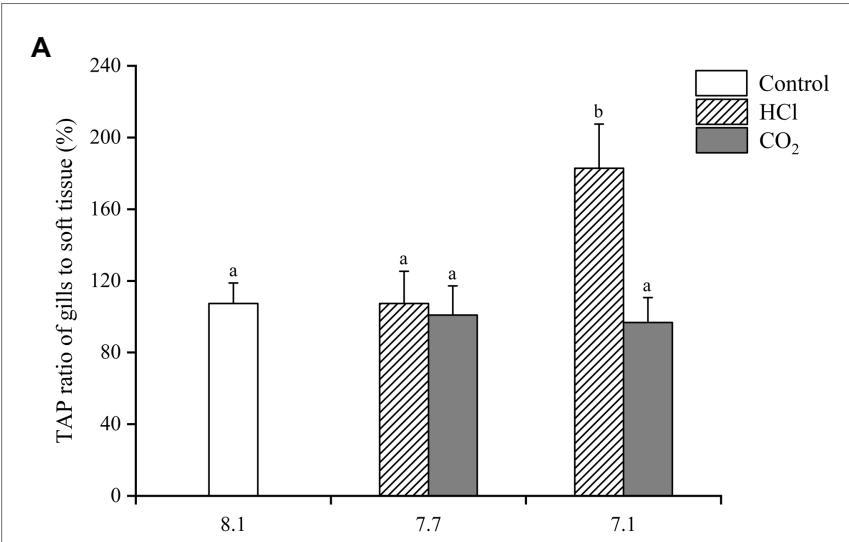

B

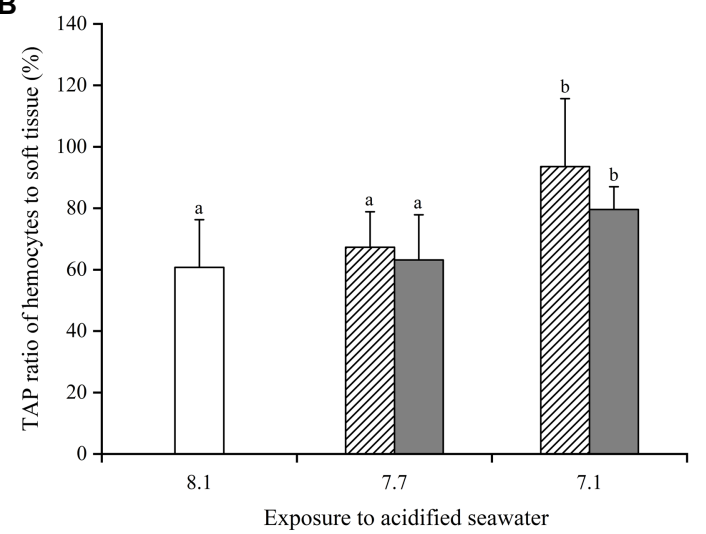

FIGURE 4 | Changes of energy allocation in gills (A) and hemocytes (B) of M. edulis under seawater acidification induced by $\mathrm{HCl}$ addition and $\mathrm{CO}_{2}$ enrichment. Data were expressed as means $\pm \operatorname{SD}(n=6)$. Different letters represent significant differences among experimental groups $(p<0.05)$.

values and lower final ATP contents were obtained simultaneously in $\mathrm{CO}_{2}$-treated groups than in $\mathrm{HCl}$-treated groups, indicating that more energy expenditure existed in $\mathrm{CO}_{2}$-treated groups, which implied that $\mathrm{CO}_{2}$ enrichment exerted greater pressure to $M$. edulis than $\mathrm{HCl}$ addition (Lannig et al., 2010; Thomsen and Melzner, 2010; Melzner et al., 2020). As gills mainly perform the functions of feeding and breathing, the vitality of the gills is important for the energy-generating processes of $M$. edulis (Doeller et al., 2001). The failure to compensate for the excessive energy consumption of the gills weakened their feeding and repair capabilities, as observed in our previous study (Xu et al., 2020). Hemocytes primarily perform immune functions in mussels (Loker et al., 2004). We found that EC in hemocytes changed little, while the ATP contents in hemocytes decreased significantly in both $\mathrm{pH} 7.7\left(\mathrm{CO}_{2}\right)$ and $7.1\left(\mathrm{CO}_{2}\right.$ and $\left.\mathrm{HCl}\right)$ treatment groups compared with the control, which further supported the assumption that seawater acidification, especially induced by $\mathrm{CO}_{2}$, resulted in the overconsumption of ATP. We tried to link the ATP content with the filtering rate, ROS production, and phagocytosis, which indicated energy intake, defensive behaviors, and immune function, respectively, and Pearson's correlation coefficients were thus calculated to present their possible linkages (Sun et al., 2017). The results demonstrated 


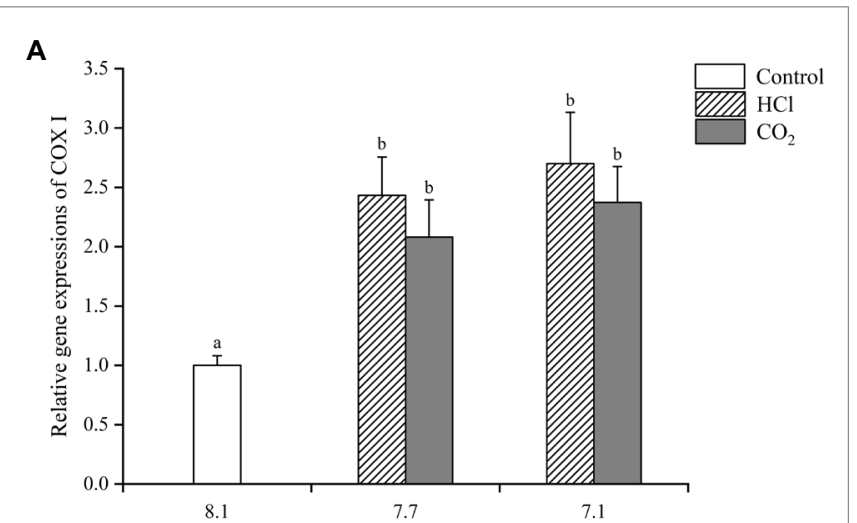

B

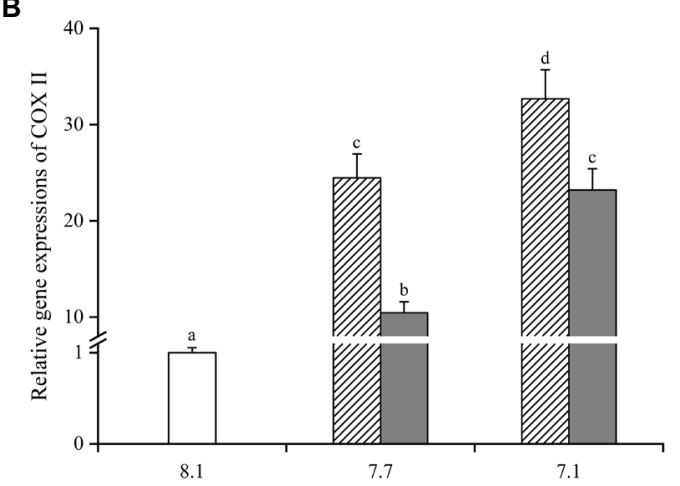

C

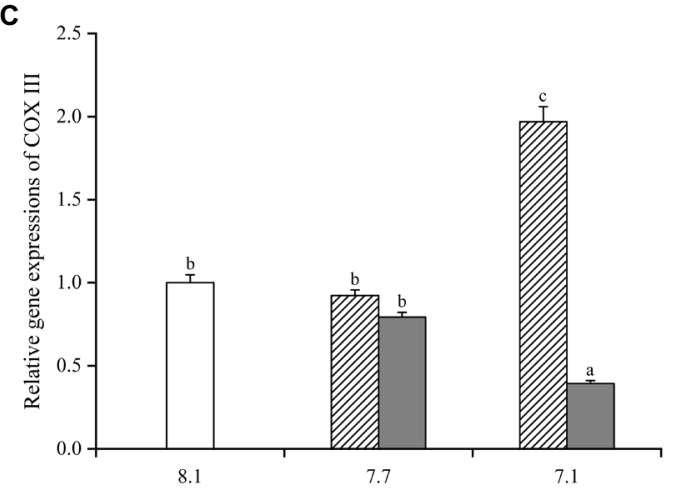

D

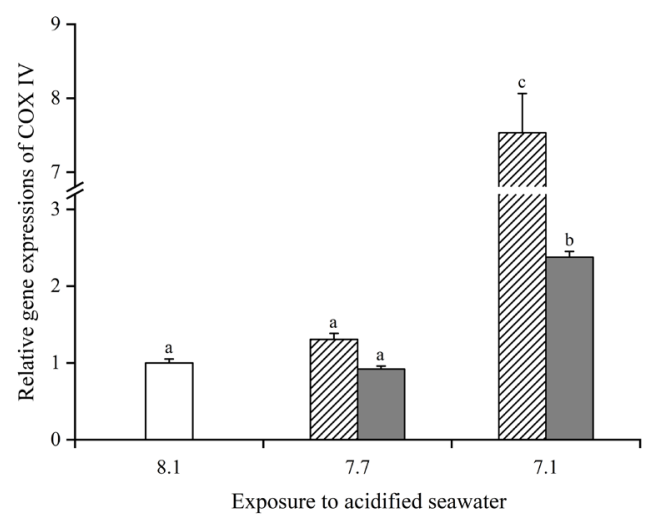

FIGURE 5 | The expression profiles of four cytochrome C oxidases (COXs) [(A): COX I; (B): COX II; (C): COX III; (D): COX IV] in gills of $M$. edulis under seawater acidification induced by $\mathrm{HCl}$ addition and $\mathrm{CO}_{2}$ enrichment. Data were expressed as means $\pm S D(n=6)$. Different letters represent significant differences among experimental groups $(p<0.05)$. a clear negative correlation between the ATP content and ROS production $(p=-0.771)$ and a positive relationship between the ATP content and phagocytosis $(p=0.732)$ in the $\mathrm{CO}_{2}$-treated groups, but no significant correlation was found in the $\mathrm{HCl}$-treated groups, which suggested that more energy was allocated to resistance to $\mathrm{CO}_{2}$ enrichment, and this was a possible explanation for why $\mathrm{CO}_{2}$ enrichment presented more detrimental impacts than $\mathrm{HCl}$ addition.

Here raised another question, namely, was the alteration of energy allocation necessary for the sustainability of $M$. edulis when facing the stress-induced decrease in energy availability? We attempted to answer this question by calculating the TAP ratios of gills and hemocytes to soft tissue. The results demonstrated that obvious energy reallocation appeared in both $\mathrm{CO}_{2}$ and $\mathrm{HCl}$ treatments at $\mathrm{pH} \mathrm{7.1,} \mathrm{but} \mathrm{it} \mathrm{was} \mathrm{more} \mathrm{effective}$ in the $\mathrm{HCl}$ treatment group than in the $\mathrm{CO}_{2}$ treatment group. This result was demonstrated by the fact that the TAP ratios of gills and hemocytes both increased significantly in the $\mathrm{HCl}$ group, while only the TAP ratio of hemocytes increased significantly in the $\mathrm{CO}_{2}$ group. Several pieces of evidence, including the lower mortality rates and higher growth indexes in $\mathrm{HCl}$ groups (Sun et al., 2016, 2017; Xu et al., 2020), have proven the necessity of energy reallocation.

The gene expressions of COXs part in gills generally increased significantly after acidification treatment, meaning a greater potential to accelerate the synthesis rate of ATP, which was consistent with the increasing trend of EC in gills. In fact, as the main rate-limiting enzyme of the mitochondrial respiratory chain, the increase in COXs gene expressions improved the efficiency of the entire respiratory chain, thus providing more energy to the cell (Achard-Joris et al., 2006), which was necessary for gills in a state of high-energy consumption. Liu and Lin (2012) also found that Pinctada martensii Dunker upregulated the expression of energy metabolism-related genes to mitigate OA damage. Achard-Joris et al. (2006) suggested that the increased expression of the COX I gene in shellfish exposed to heavy metal pollution contributed to the compensation for the decline in mitochondrial activity and coping with inner oxidative stress. In the present study, the significantly higher gene expressions of the $4 \mathrm{COXs}$ in gills in $\mathrm{HCl}$ treatment groups partly accounted for the better maintenance of the ciliary vitality and ingestion capability of its gills (Xu et al., 2020). In summary, the upregulations of the COXs gene expressions were believed to be an active response to seawater acidification at the genetic level.

We attempted to propose a hypothesis from the energy perspective, named the "cut and cover hypothesis," to intuitively explain the growth index differences between the $\mathrm{CO}_{2}$ enrichment and $\mathrm{HCl}$ addition reported in our previous studies (Figure 6). Specifically, the obtained energy was first used to meet the requirement for the survival "pit" when the organism was exposed to a stressful condition and only the remaining energy was possible for growth, which could be roughly described as "energy availability - energy for survival=energy for growth." In the present study, the energy availability in the $\mathrm{CO}_{2}$-treated group was lower, while the consumed energy for resistance was higher, that is to say, the remaining energy for growth 


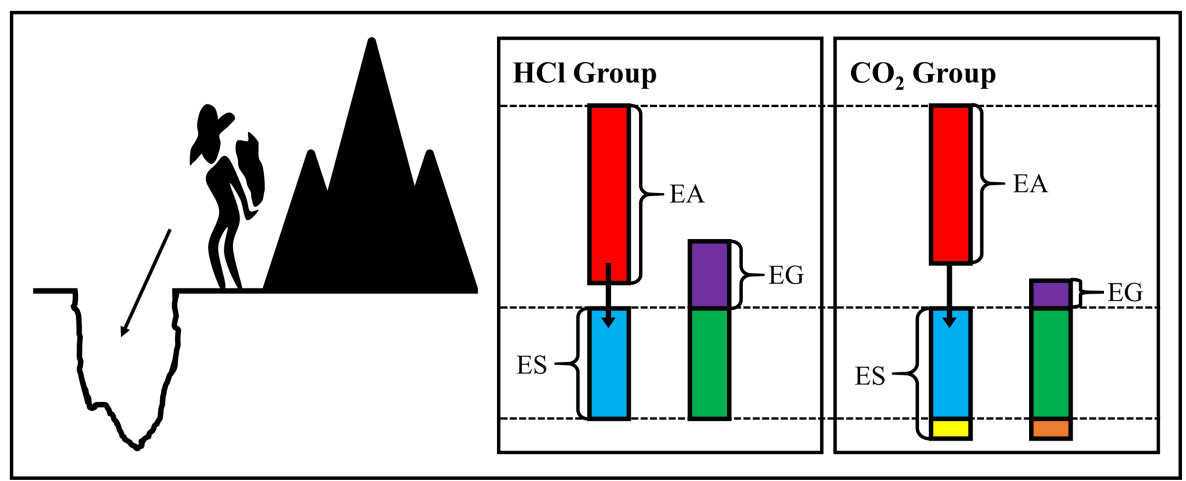

FIGURE 6 I Diagram for "cut and cover hypothesis." EA, energy availability; ES, energy for survival; EG, energy for growth.

was lower than that in the HCl-treated group. The lower dry weights of the soft tissue and the shell in $\mathrm{CO}_{2}$-treated group found in our previous study (Sun et al., 2016) provided favorable evidence for our conjecture.

In the present study, we demonstrated that acidification induced by $\mathrm{CO}_{2}$ enrichment was more deleterious than that by $\mathrm{HCl}$ addition from the perspective of energy changes. In fact, the mechanisms involved in $\mathrm{CO}_{2}$-induced acidification were much more complex than $\mathrm{HCl}$-induced acidification because dissolved $\mathrm{CO}_{2}$ affected the biological functions from the molecule to the whole organism not only through $\mathrm{H}^{+}$but also through $\mathrm{CO}_{2}$-related changes in the bicarbonate system (Pörtner et al., 2005). In the present study, we found that with increasing $\mathrm{H}^{+}$concentration in $\mathrm{CO}_{2}$-treated seawater, the partial $\mathrm{CO}_{2}$ pressure $\left(p \mathrm{CO}_{2}\right)$, carbonic acid $\left(\mathrm{H}_{2} \mathrm{CO}_{3}\right)$, and bicarbonate $\left(\mathrm{HCO}_{3}^{-}\right)$concentrations increased, while the carbonate ion concentrations $\left(\mathrm{CO}_{3}{ }^{2-}\right)$ and calculated saturation states of aragonite $\left(\Omega_{\mathrm{Ag}}\right)$ and calcite $\left(\Omega_{\mathrm{Cal}}\right)$ decreased (Table $\left.\mathbf{1}\right)$, confirming the occurrence of more complex chemical changes in $\mathrm{CO}_{2}$-acidified seawater.

$M$. edulis adapted a series of energy strategies, such as increasing the ATP synthesis rate and reallocating more energy to its gills and hemocytes, to cope with seawater acidification and thus had a certain tolerance to moderate seawater acidification. In the present study, by increasing EC and the expressions of COX I/II, the final ATP contents were successfully restored in gills and soft tissues in $\mathrm{CO}_{2}$ treatment groups at $\mathrm{pH}$ 7.7. However, with the enhancement of acidification, the failure to compensate for the excessive energy consumption was fatal for the survival of M. edulis. Meanwhile, $\mathrm{CO}_{2}$-induced acidification caused more complex chemical changes in seawater and thus exhibited more deleterious impacts on M. edulis. Moreover, owing to the presence of multiple stressors in addition

\section{REFERENCES}

Achard-Joris, M., Gonzalez, P., Marie, V., Baudrimont, M., and Bourdineaud, J. (2006). Cytochrome c oxydase subunit I gene is up-regulated by cadmium in freshwater and marine bivalves. Biometals 19, 237-244. doi: 10.1007/ s10534-005-5671-9 to elevated $p \mathrm{CO}_{2}$, the challenges are greater for M. edulis living under natural OA (Shang et al., 2018, 2020; Gu et al., 2019). If OA continues to intensify, the survival of $M$. edulis will be less likely.

\section{DATA AVAILABILITY STATEMENT}

The raw data supporting the conclusions of this article will be made available by the authors, without undue reservation.

\section{AUTHOR CONTRIBUTIONS}

YG, BZ, and YW contributed to conception and design of the study. YG, TS, and YJ carried out the experiment. YG, TS, and YZ organized the database and performed the statistical analysis. YG wrote the first draft of the manuscript. BZ wrote sections of the manuscript. All authors contributed to manuscript revision, read, and approved the submitted version.

\section{FUNDING}

This work was financially supported by the National Nature Science Foundation of China (NSFC) (No. 41776117), the Fundamental Research Funds for the Central Universities (201822005), and the NSFC-Shandong Joint Fund for Marine Ecology and Environmental Sciences (No. U1606404).

\section{ACKNOWLEDGMENTS}

The authors thank all the members of the lab for their assistance.

Atkinson, D. E. (1968). Energy charge of the adenylate pool as a regulatory parameter. Interaction with feedback modifiers. Biochemistry 11, 4030-4034. doi: 10.1021/bi00851a033

Beniash, E., Ivanina, A., Lieb, N. S., Kurochkin, I., and Sokolova, I. M. (2010). Elevated level of carbon dioxide affects metabolism and shell formation in oysters Crassostrea virginica. Mar. Ecol. Prog. Ser. 419, 95-108. doi: 10.3354/ meps08841 
Berge, J. A., Bjerkeng, B., Pettersen, O., Schaanning, M. T., and Øxnevad, S. (2006). Effects of increased sea water concentrations of $\mathrm{CO}_{2}$ on growth of the bivalve Mytilus edulis L. Chemosphere 62, 681-687. doi: 10.1016/j. chemosphere.2005.04.111

Bradford, M. M. (1976). A rapid and sensitive method for the quantitation of microgram quantities of protein utilizing the principle of protein-dye binding. Anal. Biochem. 72, 248-254. doi: 10.1016/0003-2697(76)90527-3

Caldeira, K., and Wickett, M. E. (2003). Oceanography: anthropogenic carbon and ocean pH. Nature 425:365. doi: 10.1038/425365a

Cao, R., Liu, Y., Wang, Q., Dong, Z., Yang, D., Liu, H., et al. (2018). Seawater acidification aggravated cadmium toxicity in the oyster Crassostrea gigas: metal bioaccumulation, subcellular distribution and multiple physiological responses. Sci. Total Environ. 642, 809-823. doi: 10.1016/j.scitotenv.2018.06.126

Doeller, J. E., Grieshaber, M. K., and Kraus, D. W. (2001). Chemolithoheterotrophy in a metazoan tissue: thiosulfate production matches ATP demand in ciliated mussel gills. J. Exp. Biol. 204, 3755-3764. doi: 10.1242/jeb.204.21.3755

Doney, S. C., Fabry, V. J., Feely, R. A., and Kleypas, J. A. (2009). Ocean acidification: the other $\mathrm{CO}_{2}$ problem. Annu. Rev. Mar. Sci. 1, 169-192. doi: 10.1146/annurev.marine.010908.163834

Fabry, V. J., Seibel, B. A., Feely, R. A., and Orr, J. C. (2008). Impacts of ocean acidification on marine fauna and ecosystem processes. ICES J. Mar. Sci. 65, 414-432. doi: 10.1093/icesjms/fsn048

Gattuso, J.-P., Magnan, A., Bille, R., Cheung, W. W. L., Howes, E. L., Joos, F., et al. (2015). Contrasting futures for ocean and society from different anthropogenic $\mathrm{CO}_{2}$ emissions scenarios. Science 349:aac4722. doi: 10.1126/ science.aac 4722

Gaylord, B., Hill, T. M., Sanford, E., Lenz, E. A., Jacobs, L. A., Sato, K. N., et al. (2011). Functional impacts of ocean acidification in an ecologically critical foundation species. J. Exp. Biol. 214, 2586-2594. doi: 10.1242/jeb.055939

Gazeau, F., Gattuso, J. P., Dawber, C., Pronker, A. E., Peene, F., Peene, J., et al. (2010). Effect of ocean acidification on the early life stages of the blue mussel Mytilus edulis. Biogeosciences 7, 2051-2060. doi: 10.5194/bg-7-2051-2010

Gu, H., Shang, Y., Clements, J., Dupont, S., Wang, T., Wei, S., et al. (2019). Hypoxia aggravates the effects of ocean acidification on the physiological energetics of the blue mussel Mytilus edulis. Mar. Pollut. Bull. 149:110538. doi: 10.1016/j.marpolbul.2019.110538

Guppy, M., and Withers, P. (1999). Metabolic depression in animals: physiological perspectives and biochemical generalizations. Biol. Rev. 74, 1-40. doi: 10.1017/ S0006323198005258

Hall-Spencer, J. M., Rodolfo-Metalpa, R., Martin, S., Ransome, E., Fine, M., Turner, S. M., et al. (2008). Volcanic carbon dioxide vents show ecosystem effects of ocean acidification. Nature 454, 96-99. doi: 10.1038/nature07051

Han, Y., Shi, W., Tang, Y., Zhao, X., Du, X., Liu, G., et al. (2021). Ocean acidification increases polyspermy of a broadcast spawning bivalve species by hampering membrane depolarization and cortical granule exocytosis. Aquat. Toxicol. 231:105740. doi: 10.1016/J.AQUATOX.2020.105740

Keilin, D., and Hartree, E. (1938). Cytochrome a and Cytochrome Oxidase. Nature 141, 870-871. doi: 10.1038/141870a0

Kroeker, K. J., Micheli, F., Gambi, M. C., and Martz, T. R. (2011). Divergent ecosystem responses within a benthic marine community to ocean acidification. Proc. Natl. Acad. Sci. U. S. A. 108, 14515-14520. doi: 10.1073/ pnas. 1107789108

Lannig, G., Eilers, S., Portner, H. O., Sokolova, I. M., and Bock, C. (2010). Impact of ocean acidification on energy metabolism of oyster, Crassostrea gigas-changes in metabolic pathways and thermal response. Mar. Drugs 8, 2318-2339. doi: $10.3390 / \mathrm{md} 8082318$

Liu, G. (2021). Ocean Acidification and Marine Wildlife: Physiological and Behavioral Impacts. 1st Edn. United Kingdom: Academic Press.

Liu, W., and Lin, J. (2012). Effect of seawater acidification on fertilization and early development of the pearl oyster Pinctada martensii, dunker. Mar. Sci. 36, 19-23. doi: CNKI: SUN: HYKX.0.2012-04-003

Liu, S., Shi, W., Guo, C., Zhao, X., Han, Y., Liu, G., et al. (2016). Ocean acidification weakens the immune response of blood clam through hampering the NF-kappa $\beta$ and toll-like receptor pathways. Fish Shellfish Immunol. 54, 322-327. doi: 10.1016/j.fsi.2016.04.030

Liu, Z., Zhang, Y., Zhou, Z., Zong, Y., Zheng, Y., Liu, C., et al. (2020). Metabolomic and transcriptomic profiling reveals the alteration of energy metabolism in oyster larvae during initial shell formation and under experimental ocean acidification. Sci. Rep. 10:6111. doi: 10.1038/s41598-020-62963-3
Livak, K. J., and Schmittgen, T. D. (2001). Analysis of relative gene expression data using real-time quantitative PCR and the $2^{-\Delta \Delta \mathrm{Ct}}$ method. Methods 25, 402-408. doi: 10.1006/meth.2001.1262

Loker, E. S., Adema, C. M., Zhang, S. M., and Kepler, T. B. (2004). Invertebrate immune systems - not homogeneous, not simple, not well understood. Immunol. Rev. 198, 10-24. doi: 10.1111/j.0105-2896.2004.0117.x

Melzner, F., Mark, F. C., Seibel, B. A., and Tomanek, L. (2020). Ocean acidification and coastal marine invertebrates: tracking $\mathrm{CO}_{2}$ effects from seawater to the cell. Аnпu. Rev. Mar. Sci. 12, 499-523. doi: 10.1146/annurev-marine010419-010658

Melzner, F., Stange, P., Trübenbach, K., Thomsen, J., Casties, I., Panknin, U., et al. (2011). Food supply and seawater $p \mathrm{CO}_{2}$ impact calcification and internal shell dissolution in the blue mussel Mytilus edulis. PLoS One 6:e24223. doi: 10.1371/journal.pone.0024223

Orr, J. C., Fabry, V. J., Aumont, O., Bopp, L., Doney, S. C., Feely, R. A., et al. (2005). Anthropogenic Ocean acidification over the twenty-first century and its impact on calcifying organisms. Nature 437, 681-686. doi: 10.1038/ nature 04095

Pan, T.-C. F., Applebaum, S. L., and Manahan, D. T. (2015). Experimental Ocean acidification alters the allocation of metabolic energy. Proc. Natl. Acad. Sci. U. S. A. 112, 4696-4701. doi: 10.1073/pnas.1416967112

Peng, C., Zhao, X., Liu, S., Shi, W., Han, Y., Liu, G., et al. (2017). Ocean acidification alters the burrowing behaviour, $\mathrm{Ca}^{2+} / \mathrm{Mg}^{2+}$-ATPase activity, metabolism, and gene expression of a bivalve species, Sinonovacula constricta. Mar. Ecol. Prog. Series 575, 107-117. doi: 10.3354/meps12224

Pierrot, D. E., Lewis, E., and Wallace, D. W. R. (2006). "MS excel program developed for $\mathrm{CO}_{2}$ system calculations," in ORNL/CDIAC-105a. eds. E. Lewis, and D. Wallace (Oak Ridge, Tennessee: Carbon Dioxide Information Analysis Center, Oak Ridge National Laboratory, US Department of Energy).

Pörtner, H. O., Langenbuch, M., and Michaelidis, B. (2005). Synergistic effects of temperature extremes, hypoxia, and increases in $\mathrm{CO}_{2}$ on marine animals: From earth history to global change. J. Geophys. Res. 110:2561. doi: 10.1029/2004JC002561

Rong, J., Su, W., Guan, X., Shi, W., Zha, S., Liu, G., et al. (2018). Ocean acidification impairs foraging behavior by interfering with olfactory neural signal transduction in Black Sea bream, Acanthopagrus schlegelii. Front. Physiol. 9:1592. doi: 10.3389/fphys.2018.01592

Rong, J., Tang, Y., Zha, S., Han, Y., Shi, W., and Liu, G. (2020). Ocean acidification impedes gustation-mediated feeding behavior by disrupting gustatory signal transduction in the black sea bream, Acanthopagrus schlegelii. Mar. Environ. Res. 162:105182. doi: 10.1016/J.MARENVRES.2020.105182

Shang, Y., Lan, Y., Liu, Z., Kong, H., Huang, X., Wu, F., et al. (2018). Synergistic effects of nano- $\mathrm{ZnO}$ and low $\mathrm{pH}$ of sea water on the physiological energetics of the thick shell mussel Mytilus coruscus. Front. Physiol. 9:757. doi: 10.3389/ fphys.2018.00757

Shang, Y., Wang, X., Deng, Y., Wang, S., Gu, H., Wang, T., et al. (2020). Diel-cycling seawater acidification and hypoxia impair the physiological and growth performance of marine mussels. Sci. Total Environ. 722:138001. doi: 10.1016/j.scitotenv.2020.138001

Shi, W., Han, Y., Guo, C., Zhao, X., Liu, S., Liu, G., et al. (2017). Ocean acidification hampers sperm-egg collisions, gamete fusion, and generation of $\mathrm{Ca}^{2+}$ oscillations of a broadcast spawning bivalve, Tegillarca granosa. Mar. Environ. Res. 130, 106-112. doi: 10.1016/j.marenvres.2017.07.016

Stevens, A. M., and Gobler, C. J. (2018). Interactive effects of acidification, hypoxia, and thermal stress on growth, respiration, and survival of four North Atlantic bivalves. Mar. Ecol. Prog. Ser. 604, 143-161. doi: 10.3354/ meps 12725

Su, W., Rong, J., Zha, S., Yan, M., Fang, J., and Liu, G. (2018). Ocean acidification affects the cytoskeleton, lysozymes, and nitric oxide of Hemocytes: A possible explanation for the hampered phagocytosis in blood clams, Tegillarca granosa. Front. Physiol. 9:619. doi: 10.3389/fphys.2018.00619

Sun, T., Tang, X., Jiang, Y., and Wang, Y. (2017). Seawater acidification induced immune function changes of haemocytes in Mytilus edulis: a comparative study of $\mathrm{CO} 2$ and $\mathrm{HCl}$ enrichment. Sci. Rep. 7:41488. doi: $10.1038 /$ srep 41488

Sun, T., Tang, X., Zhou, B., and Wang, Y. (2016). Comparative studies on the effects of seawater acidification caused by $\mathrm{CO} 2$ and $\mathrm{HCl}$ enrichment on physiological changes in Mytilus edulis. Chemosphere 144, 2368-2376. doi: 10.1016/j.chemosphere.2015.10.117 
Talmage, S. C., and Gobler, C. J. (2010). Effects of past, present, and future ocean carbon dioxide concentrations on the growth and survival of larval shellfish. Proc. Natl. Acad. Sci. U. S. A. 107, 17246-17251. doi: 10.1073/ pnas.0913804107

Thomsen, J., Gutowska, M., Saphörster, J., Heinemann, A., Trübenbach, K., Fietzke, J., et al. (2010). Calcifying invertebrates succeed in a naturally $\mathrm{CO}_{2}$ enriched coastal habitat but are threatened by high levels of future acidification. Biogeosciences 7, 3879-3891. doi: 10.5194/bg-7-3879-2010

Thomsen, J., and Melzner, F. (2010). Moderate seawater acidification does not elicit long-term metabolic depression in the blue mussel Mytilus edulis. Mar. Biol. 157, 2667-2676. doi: 10.1007/s00227-010-1527-0

Wang, T., and Wang, Y. (2020). Behavioral responses to ocean acidification in marine invertebrates: new insights and future directions. J. Oceanol. Limnol. 38, 759-772. doi: 10.1007/s00343-019-9118-5

Wang, M., Yang, J., Zhou, Z., Qiu, L., Wang, L., Zhang, H., et al. (2011). A primitive toll-like receptor signaling pathway in mollusk Zhikong scallop Chlamys farreri. Dev. Comp. Immunol. 35, 511-520. doi: 10.1016/j.dci.2010.12.005

Wittmann, A. C., and Pörtner, H.-O. (2013). Sensitivities of extant animal taxa to ocean acidification. Nat. Clim. Chang. 3, 995-1001. doi: 10.1038/ nclimate 1982

Xu, Y., Liu, P., and Li, Y. (2005). Effect of alcohol on brain mitochondria development of mouse embryos. J. Hyg. Res. 34, 61-63. doi: CNKI: SUN: WSYJ.0.2005-01-022

$\mathrm{Xu}$, M., Sun, T., Tang, X., Lu, K., Jiang, Y., Cao, S., et al. (2020). $\mathrm{CO}_{2}$ and $\mathrm{HCl}$-induced seawater acidification impair the ingestion and digestion of blue mussel Mytilus edulis. Chemosphere 240:124821. doi: 10.1016/j. chemosphere.2019.124821

Zhang, H., Jiang, N., Liu, G., Zhou, W., Zhang, Y., and Du, Q. (2016). An ion-pair reversed-phase HPLC method for analyzing the ATP, ADP and AMP contents in hippocampus of mice. J. Int. Pharma. Res. 43, 1151-1155. doi: 10.13220/j.cnki.jipr.2016.06.023

Zhang, H., Song, L., Li, C., Zhao, J., Wang, H., Qiu, L., et al. (2008). A novel C1q-domain-containing protein from Zhikong scallop Chlamys farreri with lipopolysaccharide binding activity. Fish Shellfish Immunol. 25, 281-289. doi: 10.1016/j.fsi.2008.06.003

Zhao, X., Guo, C., Han, Y., Che, Z., Wang, Y., Liu, G., et al. (2017a). Ocean acidification decreases mussel byssal attachment strength and induces molecular byssal responses. Mar. Ecol. Prog. Ser. 565, 67-77. doi: 10.3354/meps11992

Zhao, X., Han, Y., Chen, B., Xia, B., Qu, K., and Liu, G. (2020). $\mathrm{CO}_{2}$-driven ocean acidification weakens mussel shell defense capacity and induces global molecular compensatory responses. Chemosphere 243:125415. doi: 10.1016/j. chemosphere.2019.125415

Zhao, X., Shi, W., Han, Y., Liu, S., Guo, C., Liu, G., et al. (2017b). Ocean acidification adversely influences metabolism, extracellular $\mathrm{pH}$ and calcification of an economically important marine bivalve, Tegillarca granosa. Mar. Environ. Res. 125, 82-89. doi: 10.1016/j.marenvres.2017.01.007

Zhu, H., Wu, D., and Wang, H. (2017). Quantification of intracellular adenosine 5'-triphosphate and its metabolites by high performance liquid chromatography analysis. Chin. J. Chromatogr. 35, 54-58. doi: 10.3724/SP.J.1123.2016.08031

Conflict of Interest: The authors declare that the research was conducted in the absence of any commercial or financial relationships that could be construed as a potential conflict of interest.

Publisher's Note: All claims expressed in this article are solely those of the authors and do not necessarily represent those of their affiliated organizations, or those of the publisher, the editors and the reviewers. Any product that may be evaluated in this article, or claim that may be made by its manufacturer, is not guaranteed or endorsed by the publisher.

Copyright (C) 2021 Guo, Zhou, Sun, Zhang, Jiang and Wang. This is an open-access article distributed under the terms of the Creative Commons Attribution License (CC BY). The use, distribution or reproduction in other forums is permitted, provided the original author(s) and the copyright owner(s) are credited and that the original publication in this journal is cited, in accordance with accepted academic practice. No use, distribution or reproduction is permitted which does not comply with these terms. 